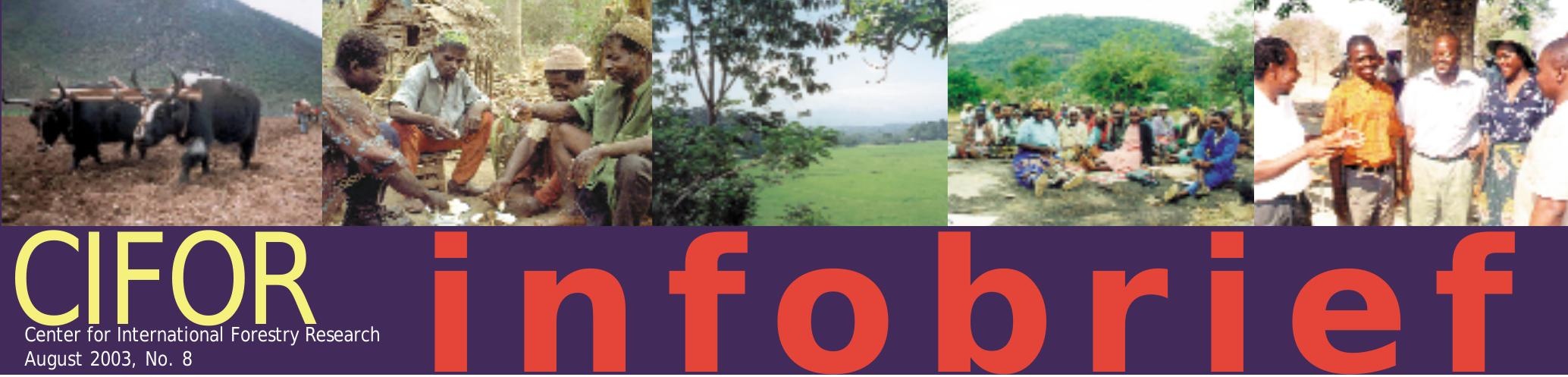
August 2003, No.

\title{
Bridging the gap: Communities, forests and international networks
}

\section{Key points}

- Few international networks have direct local impacts. Most focus on providing information and services to national level actors, helping develop resources and skills to promote national and local change. Better links between international, national and local levels need to be fostered.

- Networking has proved helpful in many countries but much more needs to be done to insert international policy gains into national reform platforms.

- Maintaining trust and links with and between communities requires investments of time and resources. Communications strategies need to ensure communities are being reached, without over-reliance on computers (which can exclude their effective participation).

- Community forestry and networking need sustained support to build social movements and community based links - support that promotes accountability without imposing artificial goals or structures.

- Participatory evaluation helps networks reflect on their effectiveness and ability to reach those they seek to include. Networks must take care to recognise their inherent limitations and also, not substitute themselves for the voice of local communities.

- Multi-stakeholder decision-making, new partnerships and engagements with civil society all promise new opportunities for local actors to have their voices heard but also entail further risks of social exclusion.

\section{Networking for change}

Since the mid-1980s, a number of formalised international networks have sprung up to promote community forestry and the rights of forest dependent people. They have sought to do this in diverse ways, with very different mixes of people and quite different objectives. What have been the results? What lessons can we learn from nearly two decades of networking? How can these efforts be built upon and improved?

\section{Learning lessons from international community forestry networks ${ }^{1}$}

International networks have contributed to community forestry in myriad ways. Few networks have had direct local impacts, except through a handful of pilot projects. Instead, most have focused on providing information and services to national level actors - helping to raise awareness, build consensus and equip them with the necessary knowledge, resources and skills to promote national and local change. The collective networking results have proven helpful in many countries and crucial in others, especially where donors exert considerable influence.

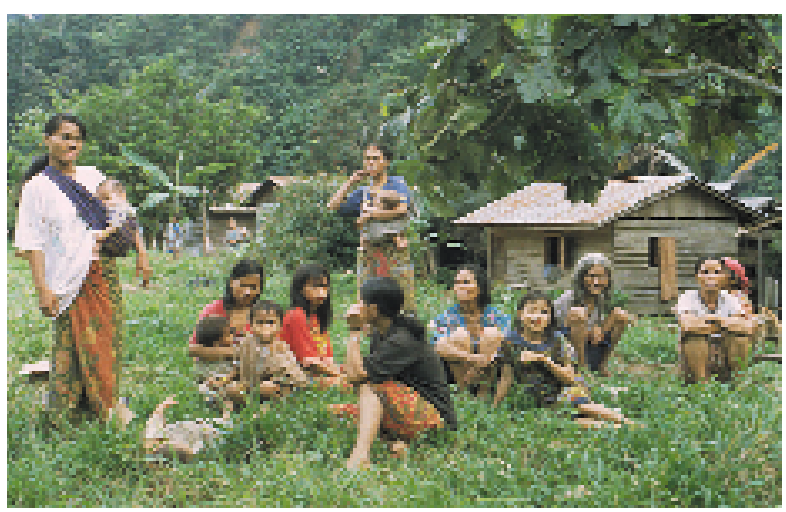

Links between international networks and national and local levels need to be improved to enhance the benefits for the rural poor. (Photo by Carol J.P. Colfer) 
On a policy level, the networks' gains in international forest policy-making have generally not yet discernibly influenced national policies, let alone had local effects. More needs to be done to insert these international policy gains into national reform platforms. On a global level, the collective networking and advocacy has fostered a growing acceptance of the validity of community forestry. New ideas for promoting it have also opened up space for local communities to reassert their rights, revalidate their institutions and customs and adapt to changing conditions.

For the networks themselves, some key lessons emerge. Firstly, networks must take care not to substitute themselves for local actors and voices, even when intending to act in solidarity with communities and social movements. They need to distinguish themselves from locally driven networks run by community representatives.

Networks also need to recognise the inherent limitations of networking and not exaggerate the extent to which they are democratic and inclusive. Collective decision-making seems to work best with less than 50 individuals or organisations, even though thousands can be reached with modern communication tools. Larger assemblies and congresses can set strategic directions and goals but to remain agile, trust in a smaller group of leaders is essential. There is an inbuilt tension between maintaining informality and flexibility and adopting structures and decision-making processes that ensure transparency and accountability. In choosing governance structures, networks need to weigh up the pros and cons and have clear reasons for their decisions.

Maintaining trust and links with and between communities requires substantial investments of time and resources. Over-reliance on computer communications can exclude the effective participation of community organisations in many countries, so networks need to ensure their communication strategies reach those they claim to include. Face to face meetings, investment in translation and interpretation and the modest use of newsletters all require adequate financing but have proved their worth, while some of the new technologies and techniques merit additional exploration.

Links between international networks and national and local levels are generally weak. In India for example, the most glaring gap in international network activity is the lack of formal links with national or local networks, even where local networks are strong and vibrant. Such links could reach a pre-existing base of community forestry actors. Sometimes the gaps occur because local groups view international networks as not relevant or top-down instead of need-based and context-driven. Foreign origins can also arouse suspicions regarding a network's political agenda.

Where there have been efforts to connect to national and local actors, networks tend to rely too much on a single national or regional focal point for communications. Their impact would be greater if they created a more diverse national and local base and could ensure capacity building and funding for these partners to follow through on their work.

\section{The Forests, Trees and People Programme 2}

The Forests, Trees and People Programme (FTPP) was launched in 1987, with global headquarters at FAO in Rome and support from a multi-donor trust fund. FTPP worked through regional and national institutions in Asia, Latin America, Africa and Europe until December 2002 and had three main objectives: (1) to develop tools, methods and approaches for participatory forestry; (2) to strengthen the abilities of local and national institutions to work in participatory forestry and related fields; and (3) to share information and experiences on innovative methods and approaches. Rather than directly targeting grassroots communities, it was felt that a wider impact could be achieved by working with institutions and organisations. In turn, these bodies would then work with local communities or their representatives. Southern actors were envisioned as partners, not beneficiaries - a valuable approach to networking, respectful of diverse voices and experiences.

The study revealed conflicting opinions on most issues but a number of interviewees perceived FTPP processes as vibrant, particularly in the earlier years. The main findings:

- Communication strategy: A formal communication strategy to provide clear guidelines on knowledge management and create multi-directional communication flows seems vital in such a large, diverse network. The publication unit's strategy was largely successful, although there were some gaps in terms of translating material.

- Monitoring and evaluation: Not having a formal monitoring and evaluation strategy led to a lack of clarity regarding FTPP's impacts, particularly at a grassroots level. Monitoring and evaluation tools need to be developed which take into account processes as well as products, since many network activities are process-oriented.

- Leadership: The network should not be reliant on one particular individual and his/her style of working but rather, on institutionalised strategies and mechanisms. This is more conducive to long term sustainability and building institutional memory and continuity.

- Institutional arrangements: Being housed in a large, bureaucratic organisation may have limited the flexibility and decentralisation FTPP needed. Infrequent face to face contact between members may have been a problem in terms of building personal relationships, although FTPP's size and the high cost of bringing members together was a significant factor.

- Donors: Donors need to be more willing to learn lessons from network experiences and include their own actions in the analysis. They also need to demand more substantial reporting to gauge network impacts. 


\section{The World Conservation Union's Working Group on Community Involvement in Forest Management ${ }^{4}$}

Building on a Ford Foundation initiative to promote international forest policy reforms favouring community forestry, the Working Group on Community Involvement in Forest Management was created in 1996, with the World Conservation Union (IUCN) as network secretariat.

This international network's goals were to: accelerate two-way learning between nations and across regions; channel the lessons learned from successful local experiences into global policy-making; promote decentralisation of forest management; and encourage donors to support community forestry. Action focused on six regions, with the UN Intergovernmental Panel on Forests (IPF) being the main target for advocacy. The Working Group emphasised the need to: amplify society's demands for a greater role in forest management; analyse regional and national trends in policy evolution; identify the main obstacles to reform; assess the role of the private sector; and document the means of transition towards greater community control of forests.

The Working Group met at least twice a year between 1996 and 2000, after which funding largely dried up. Most meetings coincided with IPF and Intergovernmental Forum on Forests (IFF) meetings and advocated the adoption of official language supportive of community involvement in forest management. This advocacy was successful, although the IPF and IFF Proposals for Action have not yet been widely implemented at the national level.

The Working Group also sponsored regional studies on the status of community forest management, resulting in detailed regional profiles on North America, Meso-America, Western Europe, South Asia and Southeast Asia, plus reports on Eastern and Southern Africa. These profiles contain a wealth of valuable information about community forestry but are too detailed and discursive to serve immediately as tools for advocacy. The Working Group generally had little lasting engagement with regional networks or community social movements following publication of the reports. However, the Meso-American and African processes, developed with extra funding, allowed for much more interactive processes, inputs into regional advocacy and local capacity building.

The main network members were described as "highly experienced individuals who have often acted as change agents and leaders". Two thirds were from the North, predominantly from NGOs, government and intergovernmental organisations and there were few direct links with community based and indigenous peoples' organisations. The governance structure was light and secretariatdriven and members did not devolve authority to a steering committee.

Inbuilt self-evaluation resulted in useful lessons for a proposed second phase, which never received funding. Improvements were canvassed in regional advocacy and capacity building, with stronger grassroots membership and decision-making engagement. Other lessons from the network experience include:

- Technical publications have limited usefulness and should be complemented with simpler stand alone summaries for wider dissemination and advocacy use.

- Publication in the major UN languages is vital for effective intercontinental linkages.

- More engagement with local social movements is necessary if regionally targeted advocacy is to have legitimacy and effectiveness in promoting change.

- Centralised, secretariat-driven networks end up having passive members. More engaged and accountable governance mechanisms are needed.

- Self-evaluations provide for crucial reflection and assess the network's value to the membership.

- Information dissemination should target libraries and resource centres and not just individuals, NGOs and institutions.

\section{Endnotes}

1 The authors reviewed seven countries' experiences with community forestry networks - Mexico, Brazil, Cameroon, Uganda, India, Indonesia and China. Nine community forestry networks were also studied, assessing how much 'value-adding' they provided, or could potentially provide, to local and national activities and also, their ability to advocate internationally for community forestry. These networks included: Coordinadora Indigena y Campesina de Agroforesteria Comunitaria (Central American Coordination for Indigenous and Peasant Community Agroforestry, ACICAFOC); Forest Stewardship Council's Social Working Group (FSC-SWG); World Conservation Union's Working Group on Community Involvement in Forest Management (IUCN-CIFM); World Rainforest Movement (WRM); Rural Development Forestry Network (RDFN); Forest Action Network (FAN); Regional Community Forestry Training Centre for Asia and the Pacific (RECOFTC); Asia Forest Network (AFN); and the Forests, Trees and People Programme (FTPP).*

2 Apte T. 2002 Lessons from the Forest, Trees and People Programme Network. Ms.

3 Laforge M. 2002 Learning Lessons from the Central American Coordination of Indians and Peasants for Community Agroforestry. Ms.

4 Colchester M. 2002 Lessons from the IUCN Working Group on Community Involvement in Forest Management. Ms.

* Copies of the full report (See notes below for reference details) may be requested from CIFOR.
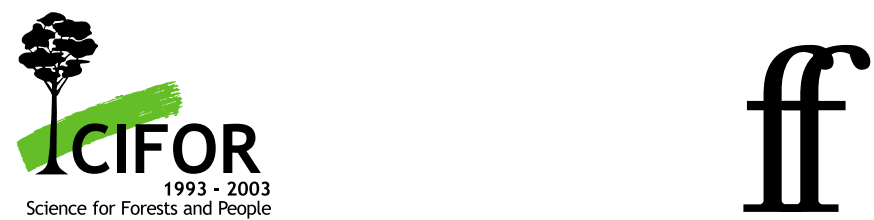

* This Infobrief is based on text from Colchester M., Apte T., Laforge M., Mandondo A. and Pathak N. 2003 Bridging the Gap: Communities, forests and international networks. CIFOR Occasional Paper No. 41. Center for International Forestry Research, Bogor, Indonesia. The U.K. Department for International Development and the Ford Foundation funded the associated programme.
Center for International Forestry Research

office: J alan CIFOR, Situ Gede, Sindang Barang, Bogor Barat 16680, Indonesia. mailing: P. O. Box. 6596 J KPWB, J akarta 10065, Indonesia Tel: +62(251) 622622 Fax: +62(251) 622100

E-mail: cifor@cgiar.org Website: www.cifor.cgiar.org Cover photos: Marcus Colchester, Edmond Dounias, Carol J.P. Colfer and Bruce Campbell

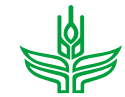

